\title{
Author Correction: Identification of functional tetramolecular RNA G-quadruplexes derived from transfer RNAs
}

\author{
Shawn M. Lyons ${ }^{1,2}$, Dorota Gudanis ${ }^{3}$, Steven M. Coyne ${ }^{1,2}$, Zofia Gdaniec ${ }^{3}$ \& Pavel Ivanov (1D 1,2,4
}

Nature Communications 8:1127 doi:10.1038/s41467-017-01278-w; Article published online: 24 October 2017

The original version of this Article contained an error in the spelling of the author Steven M. Coyne, which was incorrectly given as Stephen M. Coyne. This has now been corrected in both the PDF and HTML versions of the Article.

Published online: 05 December 2017

\begin{abstract}
(c) Open Access This article is licensed under a Creative Commons Attribution 4.0 International License, which permits use, sharing, adaptation, distribution and reproduction in any medium or format, as long as you give appropriate credit to the original author(s) and the source, provide a link to the Creative Commons license, and indicate if changes were made. The images or other third party material in this article are included in the article's Creative Commons license, unless indicated otherwise in a credit line to the material. If material is not included in the article's Creative Commons license and your intended use is not permitted by statutory regulation or exceeds the permitted use, you will need to obtain permission directly from the copyright holder. To view a copy of this license, visit http://creativecommons.org/licenses/by/4.0/.
\end{abstract}

(c) The Author(s) 2017

\footnotetext{
${ }^{1}$ Division of Rheumatology, Immunology and Allergy, Brigham and Women's Hospital, Boston, MA 02115, USA. ${ }^{2}$ Department of Medicine, Harvard Medical School, Boston, MA 02115, USA. ${ }^{3}$ Institute of Bioorganic Chemistry, Polish Academy of Sciences, Noskowskiego 12/14, 61-704 Poznan, Poland. ${ }^{4}$ The Broad Institute of Harvard and M.I.T., Cambridge, MA 02142, USA. Shawn M. Lyons and Dorota Gudanis contributed equally to this work. Correspondence and requests for materials should be addressed to Z.G. (email: zgdan@ibch.poznan.pl) or to P.I. (email: pivanov@rics.bwh.harvard.edu)
} 